\title{
Association between VEGF-2578 C>A Gene Polymorphism and Lifestyle in H. Pylori Positive Gastritis Patients
}

\author{
Mario Eka Paskah Sinulingga ${ }^{* 1}$, Ilhamd ${ }^{2}$ \\ ${ }^{1}$ Department of Internal Medicine, Faculty of Medicine, University of Sumatera Utara, Medan, North \\ Sumatera, Indonesia \\ ${ }^{2}$ Division of Gastroenterology, Department of Internal Medicine, Faculty of Medicine, Universitas \\ Sumatera Utara
}

\begin{abstract}
Background: The polymorphisms make the differences in virulence and pathogenicity of $\mathrm{H}$. pylori, which lead to different clinical manifestations after $\mathrm{H}$. pylori infection. The aim of the research to assess the correlation between VEGF2578 C>A Gene Polymorphism and lifestyle in H. Pylori (+) Gastritis Patients.

Method: The design of this study is a cross-sectional study of H. Pylori (+) Gastritis patients, independent variables is gene polymorphism VEGF-2578C >A and dependent variables are lifestyles (age, gender, BMI, and alcohol). Infection of $H$. Pylori detected ${ }^{14} \mathrm{C}-\mathrm{UBT}$ or rapid urease test. Examination of gene polymorphism VEGF-2578C $>$ A by performing DNA extraction (Spin Column Method) with reagent: High Pure PCR Template through PCR procedure.

Results: From 59 patients gastritis H. Pylori (+), there is no correlation between VEGF-2578 C>A gene polymorphism (consisting of CC, CA and AA) with lifestyle (gender, age consists of $<45$ years and $>45$ years, BMI consists of $<25$ $\mathrm{kg} / \mathrm{m}^{2}$ and $>25 \mathrm{~kg} / \mathrm{m}^{2}$, alcoholic drinkers )

Conclusion: There is no correlation between VEGF-2578 C>A Gene Polymorphism and lifestyle (age, sex, BMI, and alcohol drinking) in H. Pylori (+) Gastritis Patients.
\end{abstract}

Keywords: VEGF-2578 C>A, Gene Polymorphism, Lifestyle, H. Pylori (+) Gastritis \footnotetext{
Medan, North Sumatera, Indonesia

E-mail address: marioeka2503@gmail.com

*Corresponding author at: Department of Internal Medicine, Faculty of Medicine, University of Sumatera Utara, 
Abstrak

Latar Belakang: Polimorfisme menyebabkan perbedaan virulensi, patogenitas, manifestasi klinis infeksi H. pylori. Tujuan penelitian untuk menilai korelasi antara VEGF-2578 C>A Gene Polymorphism dan pola hidup pada pasien Gastritis dengan H. Pylori (+)

Metode: Desain penelitian ini adalah studi potong lintang pada pasien gastritis $H$. Pylori (+), variabel independen adalah polimorfisme gen VEGF-2578C >A dan variabel dependen adalah gaya hidup (usia, jenis kelamin, BMI dan peminum alkohol). Infeksi H. Pylori dideteksi dengan ${ }^{14}$ C-UBT atau tes urease cepat. Pemeriksaan polimorfisme gen VEGF-2578C>A dengan melakukan ekstraksi DNA (Spin Column Method) dengan reagen: Template PCR Murni Tinggi melalui prosedur PCR.

Hasil: Dari 59 pasien Gastritis H. Pylori (+), tidak terdapat korelasi antara VEGF-2578 C>A gene polymorphism (terdiri dari CC, CA dan AA dengan gaya hidup (jenis kelamin, usia terdiri dari < 45 tahun dan > 45 tahun, IMT terdiri dari $<25 \mathrm{~kg} / \mathrm{m}^{2}$ dan $>25 \mathrm{~kg} / \mathrm{m}^{2}$, peminum alkohol).

Kesimpulan: Tidak ada korelasi antara VEGF-2578 C>A Gene Polymorphism dan gaya hidup (usia, jenis kelamin, BMI dan minum alkohol) pada pasien Gastritis $H$. Pylori (+).

Kata kunci: VEGF-2578 C>A, Polymorphisme, Gaya Hidup , H. Pylori (+) Gastritis.

Received 02 May 2021 | Revised 30 May 2021 | Accepted 31 May 2021

\section{Introduction}

Helicobacter pylori (H. pylori) infection is a leading worldwide infectious disease that affects more than half of the world's population. $\mathrm{H}$. pylori is a gram-negative, spiral-shaped pathogenic bacterium that colonizes the gastric epithelium specifically and causes atrophic gastritis, peptic ulcer disease, and gastric malignancies [1,2]. H. pylori infection causes a chronic cellular inflammatory response in the gastric mucosa. However, the effects of this local inflammation may not be confined to the digestive tract and may result in extra- digestive conditions [3], such as osteoporosis [4]. On the other hand, the malabsorption of dietary calcium may be a crucial cause of osteoporosis [5].

The polymorphisms make the differences in virulence and pathogenicity of H. pylori, which lead to different clinical manifestations after $\mathrm{H}$. pylori infection. The attention paid to the research about gene polymorphisms and pathogenicity of $\mathrm{H}$. pylori is getting high. Pathogenicity of $\mathrm{H}$. pylori-related genes including vacuolating cytotoxin (vacA) and cytotoxin associated protein (CagA) has been well studied [6]. Among other factors involved in complex steps of gastric 
carcinogenesis including H.pylori infection, individual susceptibility has shown to be involved, one of which includes polymorphisms of vascular endothelial growth factor (VEGF) gene. The research on 100 populations of VEGF-2578C > A polymorphism has genotypes consisting of CC $32 \%$, CA 39\%, and AA 29\% (Tzanakis et al, 2005). Polymorphism VEGF-2578 C>A with increased serum VEGF may be due to the role of allele $\mathrm{C}$. While research in China, there are no polymorphic relationships between VEGF - $2578 \mathrm{C}>\mathrm{A}$ and development, risk, prognostic, and survival of gastric cancer [7]. Many studies on the relationship of VEGF polymorphism-2578 $\mathrm{C}>\mathrm{A}$ to the risk of stomach cancer but there is still no research on polymorphism VEGF-2578 C>A against age, gender and body age index.

The present work aimed to study the associations of polymorphism-2578 C>A of pathogenic $\mathrm{H}$ pylori with age, sex, and BMI in gastritis patients.

\section{Method}

The design of this study is a cross-sectional study with independent variables is polymorphism VEGF-2578C >A and dependent variables are age, gender, and BMI. The target population of the study was H. pylori (+) gastritis patients, Inclusion criteria were histopathologically confirmed gastritis, age 18 and older, and were willing to take part in the study. Patients who received any regimens of $\mathrm{H}$. pylori eradication therapy within the last 6 months, or were currently on antibiotics commonly used in $\mathrm{H}$. pylori treatment, currently pregnant, had prior gastric surgery, suspected for developing frank gastric malignancy, or currently taking proton pump inhibitor or $\mathrm{H} 2$ antagonist receptor were excluded from the study. Infection of $\mathrm{H}$. Pylori detected 14C-UBT or rapid urease test. Examination of polymorphism VEGF-2578C $>$ A by performing DNA extraction (Spin Column Method) with reagent: High Pure PCR Template through PCR procedure.

\section{Data Analysis}

Statistics analyses were carried out using the IBM SPSS Statistics 20.0 software (IBM). To approximate normality of sex age and BMI were natural log-transformed for the analysis. We calculated the ANOVA between gene polymorphism VEGF- $2578 \mathrm{C}>\mathrm{A}$ and lifestyle (sex, BMI, age, and alcohol drinking). All statistical tests were two-sided, with $\mathrm{p}<0.05$ as the boundary value.

\section{Results}

The number of research samples is 59 patients consisting of the female and male gender, age consists of $<45$ years and $>45$ years, BMI consists of $<25 \mathrm{~kg} / \mathrm{m} 2$ and $>25 \mathrm{~kg} / \mathrm{m} 2$, alcohol and gene polymorphism consists of CC, CA and AA (Table 1). 


\begin{tabular}{llc}
\multicolumn{2}{c}{ Table 1 } & \multicolumn{2}{c}{ Characteristic of patiens } \\
\hline \multicolumn{1}{c}{ Parameters } & & $\mathrm{n}$ \\
\hline Sex $(\mathrm{N})$ & female & 30 \\
& male & 29 \\
Age (years) & $<45$ & 18 \\
& $>45$ & 41 \\
BMI $\left(\mathrm{Kg} / \mathrm{M}^{2}\right)$ & $<25$ & 47 \\
& $>25$ & 12 \\
Alcohol & + & 10 \\
& - & 49 \\
Polymorpism $(\mathrm{N})$ & $\mathrm{CC}$ & 29 \\
& $\mathrm{CA}$ & 21 \\
& $\mathrm{AA}$ & 9 \\
\hline
\end{tabular}

In table 2, there is no correlation between Polymorphism and sex, age, BMI and alcohol

Table 2 Correlation between Polymorpism and Sex, Age, BMI and Alcohol

\begin{tabular}{|c|c|c|c|c|c|c|}
\hline & \multirow[t]{2}{*}{ Parameters } & \multirow[t]{2}{*}{$\mathrm{n}$} & \multicolumn{3}{|c|}{ Polymorphism } & \multirow[t]{2}{*}{$\mathrm{p}$} \\
\hline & & & $\mathrm{CC}$ & $\mathrm{CA}$ & AA & \\
\hline \multirow[t]{2}{*}{$\operatorname{Sex}(N)$} & female & 30 & 13 & 11 & 6 & 0.511 \\
\hline & male & 29 & 16 & 10 & 3 & \\
\hline \multirow[t]{2}{*}{ Age (years) } & $<45$ & 18 & 9 & 7 & 2 & 0.829 \\
\hline & $>45$ & 41 & 20 & 14 & 7 & \\
\hline \multirow[t]{2}{*}{$\mathrm{BMI}\left(\mathrm{Kg} / \mathrm{M}^{2}\right)$} & $<25$ & 47 & 23 & 18 & 6 & 0.493 \\
\hline & $>25$ & 12 & 6 & 3 & 3 & \\
\hline \multirow[t]{2}{*}{ Alcohol } & + & 10 & 7 & 3 & 0 & 0.222 \\
\hline & - & 49 & 22 & 18 & 9 & \\
\hline
\end{tabular}

\section{Discussion}

The VEGF gene is located on chromosome 6 located at 6 p21.1 which consists of 8 exons separated by 7 introns and is highly polymorphic (has 140 variants). Single Nucleotide Polymorphisms (SNP) are inherited genetic variations commonly found in human genes. SNP is a genetic variation that occurs when a single nucleotide, namely adenine (A), thymus (T), cytosine $(C)$, or guanine $(\mathrm{G})$ changes in genome sequence and is derived. Polymorphism does not cause changes in protein structure but only results in variations in protein function. VEGF gene polymorphism can be found in many different locations and influences the risk of cancer development [8].

VEGF has a role in the path of carcinogenesis by mechanisms as an inhibitor of apoptosis, tumor development, angiogenesis, invasion, and metastasis. VEGF polymorphism is thought to have a risk to the process of carcinogenesis but the mechanism is not yet clear [9]. Polymorphism VEGF $-2578 \mathrm{C}>\mathrm{A}$ can affect the production of VEGF proteins [10]. Variations in alleles can lead to overexpression of transcription factors that serve as the site of the binding of the initial RNA polymerase that will initiate transcription [11].

Changes in the sequence of DNA alleles can alter the production or activation of VEGF which can lead to the growth of different tumors between individuals. The contribution of VEGF 
polymorphism to VEGF serum levels depends on the location variant of a particular VEGF gene. VEGF located in 3'unstranslated gene region i.e. VEGF-935 C>T polymorphism can affect plasma VEGF levels [12].

In this research, there is no correlation between VEGF-935 $\mathrm{C}>\mathrm{T}$ polymorphism and age, sex, BMI, and alcohol in gastritis H pylori patients. The impact of alcohol drinking on gastric cancer development according to $\mathrm{H}$ pylori infection status [13] and incidence of $\mathrm{H}$. pylori infection can be affected by hygienic conditions and socioeconomic status [14]. However, pathogenic analysis of $\mathrm{H}$. pylori is very difficult due to the presence of unknown pathogenic genes, which involvement of multiple factors in diseases induced by gene polymorphism of $\mathrm{H}$. pylori infection, and the combination of many types of strains in the same patient. Thus further study on the relationship between genetic polymorphisms of $\mathrm{H}$. pylori and its associated clinical diseases should be conducted to fully illustrate the pathogenicity of $\mathrm{H}$. pylori.

\section{Conclusion}

In this research, there is no correlation between VEGF-2578 C>A Gene Polymorphism and lifestyle (age, sex, BMI, and alcohol drinking) in H. Pylori (+) Gastritis Patients

\section{REFERENCES}

[1] A. C. Wotherspoon, C. Ortiz-Hidalgo, M. R. Falzon, and P. G. Isaacson, "Helicobacter pylori-associated gastritis and primary B-cell gastric lymphoma," The Lancet, vol. 338, no. 8776 , pp. 1175-6, 1991.

[2] J.Parsonnet, "Helicobacter pylori and gastric cancer,"Gastroenterology Clinics of North America, vol. 22, no. 1, pp. 89-104, 1993.

[3] M. Kowalski, P. C. Konturek, P. Pieniazek et al., "Prevalence of Helicobacter pylori infection in coronary artery disease and effect of its eradication on coronary lumen reduction after percutaneous coronary angioplasty," Digestive and Liver Disease, vol. 33, no. 3, pp. 222-9, 2001.

[4] R. Pacific, "Cytokines, estrogen, and postmenopausal osteoporosis the second decade," Endocrinology, vol. 139, no. 6, pp.2659-61, 1998.

[5] P. Sipponen and M. Ha rko nen, "Hypochlorhydric stomach: a risk condition for calcium malabsorption and osteoporosis?" Scandinavian Journal of Gastroenterology, vol. 45, no. 2, pp. 133-8, 2010.

[6] Chen YL, Mo XQ, Huang GR, Xiao J, Zhao LJ, Wei HY and Liang Q, Gene polymorphisms of pathogenic Helicobacter pylori in patients with different types of gastrointestinal diseases, Vol 22, no.28;p.44. 2016

[7] Liu, W. Dong Z, Hu R, Wang C. Association of Vascular Endtohelial Growth Factor (VEGF) Gene polymorphism with gastric cancer and its develepment, Prognosis, and survival. SagePub. Vol.17: pp.1-8. 2018 
[8] Krippl P, Langsenlehner U, Renner W, Yazdani-Biuki B, Wolf G, Wascher TC, et al. A common $936 \mathrm{C} / \mathrm{T}$ gene polymorphism of vascular endothelial growth factor is associated with decreased breast cancer risk. Int J Cancer vol.106, pp.468-71. 2003

[9] Zhou, LP, Yao M, Lee T, Yi Zhu, Martins-Green M, Y-J Shyy J. Vascular Endothelial Growth Factor $+936 \mathrm{C} / \mathrm{T}$ polymorphism and gastric cancer risk : A meta-analysis. Experimental \& Therauphetic Medicine. Vol.2, pp.931-6. 2011

[10] Al Habboubi, Sater MS, Almawi AW, Al-Khateeb GM, Almawi WY. Contribution of VEGF polymorphism to variation in VEGF serum level in healthy population. Eur.Cytokine Net, vol.22, no.3,pp.154-8. 2011

[11] Corvalan AH, Carrasco G, Saavedra K. The genetic and epigenetic bases of gastritis. In Mozsik G, ed. Current Topics in Gastritis. InTech. p.79-95. 2012.

[12] Siregar, G. A., Parwati, I., Achmad, T. H., \& Syukriani, Y. F. (Association between vegf$634 \mathrm{~g}>\mathrm{c}$ gene polymorphism with gastric premalignant lesions and serum vegf levels in helicobacter pylori gastritis patients. Open Access Macedonian Journal of Medical Sciences, vol.6, no.8, pp.1328-34. 2018 https://doi.org/10.3889/oamjms.2018.266

[13] Ma SH, Jung W, Weiderpass E, Jang J, Hwang Y, Ahn C, et al. Impact of alcohol drinking on gastric cancer development according to Helicobacter pylori infection status. British Journal of Cancer vol.113, pp.1381-8. 2015

[14] Wang W, Jiang W, Zhu S, Sun X, Li P, Liu K, et al. Assessment of prevalence and risk factors of helicobacter pylori infection in an oilfield Community in Hebei, China. BMC Gastroenterology vol.19, no.186. 2019 